\title{
Pneumatic Press for Cold Bending of Metal Elements
}

\author{
Joanna Cyganiuk* \\ University of Zielona Góra, Faculty of Mechanical Engineering, 4 Szafrana Street, 65-246 Zielona Góra, Poland
}

\begin{abstract}
The paper presents a pneumatic three-cylinder press designed for the formation of elements made of steel sheet with the cold working method. Pipe clamps supporting pipes are the elements to be formed. The paper presents the press construction, its application, basic parameters including obtained load, as well as an electropneumatic system controlling the press together with its electric system. Manual control of the press as well as its automatic work mode were assumed. The paper does not include a pneumatic system doubling the work of the electropneumatic system because of its complexity.
\end{abstract}

Keywords: Press, electropneumatics, bendig, automation.

\section{Introduction}

The appliances most often used in the plastic working processes are hydraulic appliances (e.g. hydraulic press), but pneumatic and pneumatic-hydraulic systems are also used. Electrohydraulic or electropneumatic systems are used in appliances that generate pressure on the formed material. Electrohydraulic systems used in presses are designed to exert higher forces and stresses in the formed material than electropneumatic systems.

Cylinders used in hydraulic appliances achieve considerably higher values of forces on its piston rod while its moving out movement, than cylinders in pneumatic systems (even 100 times higher) [11].

Pneumatic systems in plastic working work as pneumatic bending machines for pipes with small diameters [13], or as single-cylinder pneumatic or pneumatichydraulic presses $[9,10,12]$.

Loads achieved by pneumatic presses amount e.g. from 1 kN to 320 kN $[9,10]$. In the case of pneumatic-hydraulic presses, loads are higher and amount e.g. from 250 $\mathrm{kN}$ to $750 \mathrm{kN}$ [12]. However, in this type of appliances, an increase in the pressure of cylinders is obtained by the use of hydraulic multiplier, driven by compressed air. This type of presses are used mainly as hand-operated appliances, and multiplier is designed to increase the load of the press and to reduce the load on operating lever by the operator.

Appliances, operation of which can be automated, are appliances with hydraulic or pneumatic drives [5]. Operation of these drivers is controlled by electric systems. The best solution is the possibility of both manual start of the press and its automatic start. The automatic operation of the appliance allows cooperating with manipulators/robots.

In the further part of the article, a three-cylinder pneumatic press, which forms sheets with the cold bending method and is designed for automatic and manual operation, is presented. 


\section{Three-cylinder Pneumatic Press with Electric Control}

As the name implies, the press in its construction includes three pneumatic cylinders with the maximum load $20 \mathrm{kN}$ each one. The maximum load can be achieved with the 6 bar pressure.

The basic components of the press (Fig 1.) are: cylinders (1), piston rods (2) which are led in sleeves (3). Special shaped punches (4), designed to form a material, are fastened to cylinders. Dies (5), in which material deepens while it is pressed by a punch, are fastened to press tables. All the construction rests on a frame (6), whereas pushbuttons (7) allow the manual start of the press (three cylinders at the same time). The structure of the press allows changing both: the punch and the die. It enables the formation of elements with a developable surface and with a non-developable surface, of different form shapes than the ones of the punch and the die shown in Figure 1. The press is also equipped with a master switch, which allows air to the electropneumatic system.

The press is equipped with the securing means, which block its start when the operator's hand or maniplulator's/robot's gripper is within the die area. Sensors detecting any unwanted objects are capacitive detectors, which detect both human body or elements made of metal or non-metal. The protection was performed for all three dies.

Another securing means, mounted on the press, are sensors detecting the material in the die. The control system was designed to prevent the punch from exerting pressure directly on the die. In this case, the press can only be started, when three dies are filled with material to be formed. Sensors that detect the material in the die are also capacitive sensors mounted on the press in a way that allows detecting only the material placed in the die.

The important part of the press are sensors that detect the position of the piston in the cylinder. By analyzing this position (inside/outside) any stroke of the piston in which it moves back to the initial position can be used. For the presented press, the stroke is equal to the half of the normal stroke of the applied cylinder. The half of the stroke is used because of possible buckling of the piston rod. Proximity detectors, which detect magnetic inserts mounted in press pistons, were used.

The punch and the die mounted on the press are designed to form an element used as a pipe clamp.
The initial element made from C45 material with $217 \times 30 \times 5 \mathrm{~mm}$ dimensions were taken to strength analysis of the finished product. The shape of the finished product is shown in Figure 2.

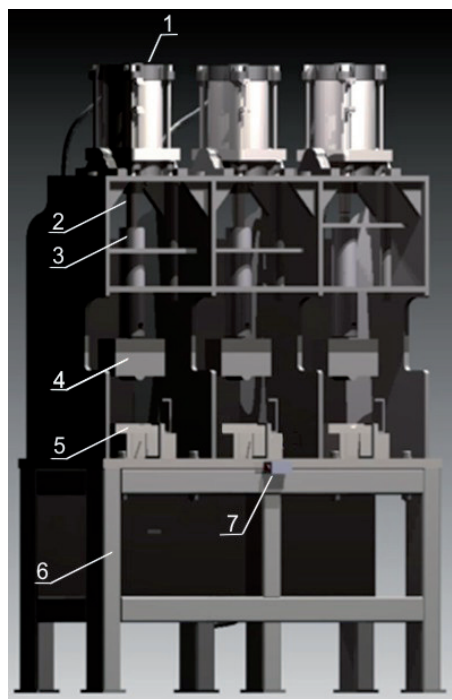

Fig. 1: Three-cylinder pneumatic-press controlled by an electric system [8]

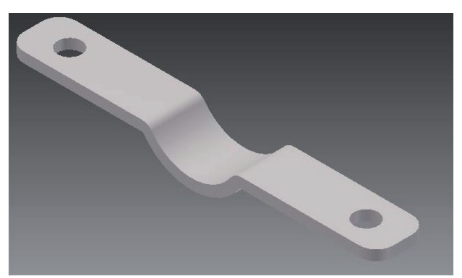

Fig. 2: Pipe clamp - the shape of the formed element [8]

\subsection{Electropneumatic system of a three-cylinder press}

The elctropneumatic system used in the press works as an executive system. Three identical cylinders were applied, on which suitably designed punches are fastened. As it was mentioned, the system is applied with the cylinders equipped with magnetic inserts. Apart from cylinders, the electropneumatic system includes one-way flow control valves, which allow regulation of the velocity of the piston movement, while both the bending process (the piston rod move out) and when the piston rod moves back to the cylinder. Each cylinder is equipped in this type of valves. They are mounted at the front end and at the head end of the cylinder. The cylinders are driven with the use of compressed air with the pressure from 4 bar to 6 bar. The air is fed with the use of bistable, five- 
way, two-positioned distribution valve controlled by an electromagnetic impulse, induced by coils. Each valve is additionally equipped with silencers, thanks to which the system operates quietly.

Figure 3 presents the method of the control of one of the cylinders of the three-cylinder pneumatic press.

The electropneumatic system is also equipped with the compressed air preparation unit consisted of a filter and a pressure reducing valve, which allows controlling the operating pressure in the pneumatic system.

The last important part of the system is a monostable, two-way, two-positioned distribution valve, controlled in the same way as $5 / 2$ valves, which cuts off the compressed air to the system. It is an additional protection means used in case of failure of the pressure reducing valve.

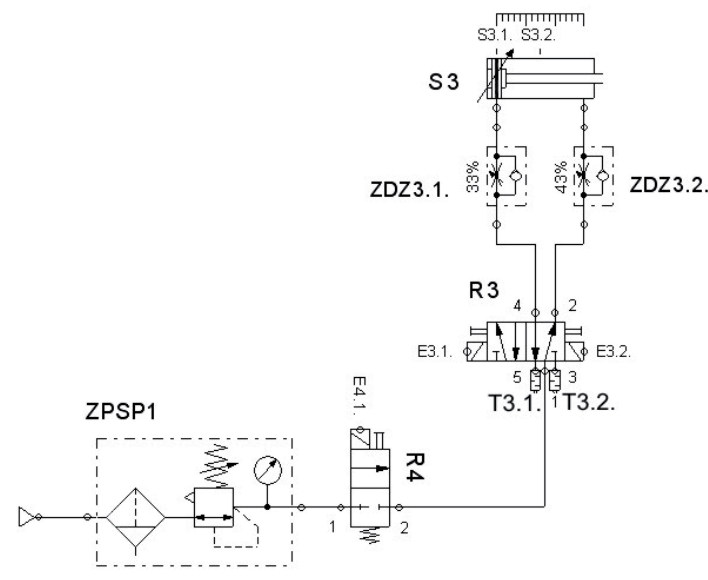

Fig. 3: Electropneumatic system of the three-cylinder pneumatic press - scheme for one of the three applied cylinders.

The system presented in Figure 3 includes the following elements: positions of proximity detectors S3.1. and S3.2., a double acting cylinder S3, one-way flow control valves ZDZ3.1. and ZDZ3.2., a bistable 5/2 distribution valve R3 electrically controlled with coils E3.1. and E3.2. Silencers T3.1. and T3.2. which are screwed to valve R3. The element responsible for cleaning the air flowing into the system and for setting proper working pressure is a compressed air preparation unit ZPSP1 equipped with a filter for solid particles and a reducing valve. An electrically controlled monostable $2 / 2$ valve $R 4$ is responsible for the ventilation of the system with compressed air and for blocking the airflow.

The pneumatic system can operate with the working pressure form 4 bar to 6 bar, depending on the punch load which we want to obtain. The working movement of cylinders is slower than the back movement (Fig.3.), which is indicated by the settings of flow damping on the one-way flow control valves.

The other cylinders operating in the systems similar to the one in Figure 3., and the electropneumatic system itself is a very simple solution and is more economic than other types of systems that could be applied for this appliance.

Figure 4 shows a diagram of operation of the cylinders in automatic and manual work cycles.

The diagram shows the characteristic course of operation of the cylinders, which reveals that the stroke is incomplete when the piston rods move out. The description in the diagrams correspond to the one in Figure 5, which is widely discussed in point 2.2. The diagram concerning the automatic operation of cylinders does not take into consideration a standstill stage of operation i.e. removing a finished element by the grip and inserting a blank one on the die. This diagram only presents the cycle of the automated operation of the press. However, the times between the piston rods move in and out enable a free manipulation of the element within the die, i.e. cutting off the power (operation of capacitive sensors).
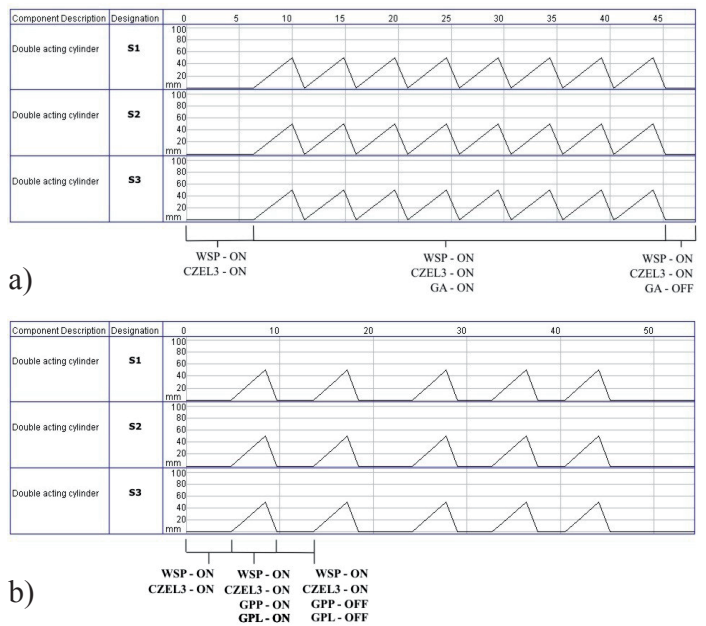

Fig. 4: Diagram of operation of the three cylinders of the pneumatic press: (a) automatic operation, (b) manually controlled operation. 


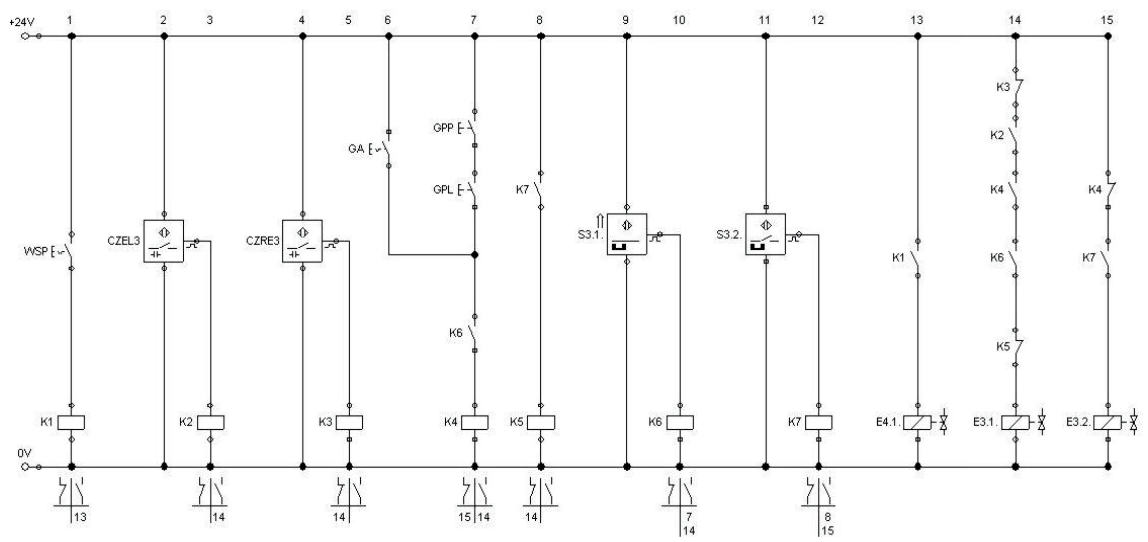

Fig. 5: Electric scheme allowing control the work of cylinders of three-cylinder pneumatic press-scheme for one of three applied cylinders.

In the case of manual operation, the diagram presents longer standstills, which result from: releasing the push buttons starting the press, removing the finished element from the die and placing a blank sheet into the die, of which the pipe clamp is to be formed.

\subsection{Electric system controlling operation of electropneumatic system of a three-cylinder press}

Because of the fact, that electric system controlling the operation of the discussed three-cylinder press is rather an extensive system, although it is not complicated, the paper presents only electric system designed for controlling of a single cylinder of the press. Like in the electropneumatic system, the electric system is presented for cylinder S3. In the presented system (Fig 5), all components controlling other cylinders were removed, what clarifies the scheme. The real system includes all components controlling the press.

The electric system allows manual operation as well as automatic operation. The presented system can be also easily adjusted to cooperation with a robot or a manipulator - if such an element is anticipated in the system. However, its actual form allows applying the system to cooperate with a manipulator/robot, thanks to capacitive sensors, detecting both: gripper near the die and the lack of material in the die and thanks to slowly movement of the piston rod. There are security and safety devices protecting the manipulator's gripper. Cylinders do not carry on its operation, either when there is no material in the die or when an intruder is detected. A signal from manipulator should be plugged in line 7 or in line 13 of the system presented in Figure 5, which will result in braking and cutting-off of the control signal, or, indirectly, the pneumatic signal (with the use R4 valve - Fig.3).

\section{Achieved Parameters of Three-cylinder Pneumatic Press}

Table 1 presents current parameters of threecylinder pneumatic press. Further modernization of both the pneumatic system and the electric system is intended. The modernization includes among others, the control voltage, the type of valves used as well as direct dependence of voltage on the pneumatic system. The current form of the appliance is its experimental form.

Table 1: Basic parameters of three-cylinder pneumatic press.

\begin{tabular}{|l|l|}
\hline Parameter name & Value \\
\hline Pressure of the punch: & $20 \mathrm{kN}$ \\
\hline for 6 bar & $17 \mathrm{kN}$ \\
\hline for 5 bar & $14 \mathrm{kN}$ \\
\hline for 4 bar & $500 \mathrm{~mm}$ \\
\hline $\begin{array}{l}\text { Cylinder's operational } \\
\text { stroke }\end{array}$ & $430 \times 380 \mathrm{~mm}$ \\
\hline Usable size of table & $530 \mathrm{~mm} / \mathrm{s}$ \\
\hline $\begin{array}{l}\text { Maximum operating spe- } \\
\text { ed of cylinders }\end{array}$ & $1670 \times 2160 \times 440 \mathrm{~mm}$ \\
\hline Press dimensions & $24 \mathrm{VDC}$ \\
\hline Coils voltage & YES \\
\hline $\begin{array}{l}\text { Possibility for punch chan- } \\
\text { ging }\end{array}$ & YES \\
\hline $\begin{array}{l}\text { Possibility for die chan- } \\
\text { ging }\end{array}$ & \\
\hline
\end{tabular}


The particular elements of the structure of the press were analyzed in terms of its structural strength. The main element of the press transferring loads and stresses is a frame made of steel pipes of a square cross-section, which met the expected strength requirements. Also the punch designed for the press as well as the die transfer the applied load without any damages.

Thanks to proper construction, the press allows changing the punch, which is seated on the piston rod as well as changing the die, which is specially designed for the press.

The presented press is suitable for small and medium batch production of elements of small dimensions, which are to be formed from iron and non-iron materials, on the condition that the forces in the forming process will not exceed the range which can be achieved by the presented threecylinder pneumatic press (Table 1).

The press is also equipped with a doubling pneumatic system, which is a protection in case of the failure of electropneumatic system. Its principle of operation is identical to the electropneumatic system, and the control has been realized basing exclusively on pneumatic elements.

The press is so simple in its construction, that can be easily done by anybody, without commission it to an external firm. The press was designed with the use of pneumatic elements of leading producers from the UE and from the USA. All components of the electric system were made in UE.

\section{Conclusions}

Three-cylinder pneumatic press, that is discussed in the article can be an alternative for hydraulic presses, on the condition that the needed punch load does not exceed $20 \mathrm{kN}$. Comparing to hydraulic systems, pneumatic systems are more ecologic, because they do not need utilization of hydraulic fluids. However, because of the noise, which is made by compressed air, this type of press without using silencers could be a bothersome problem.

The proposed press can be also used for forming bending elements of different shapes or even for stamped elements, but that would require the exchange of the punch and die.

A great advantage of the proposed appliance is the fact that it can be easily performed because its construction and controlling system are very simple. It is also possible to set the velocity with which the piston rod moves out for both working movement and for returning movement.

Essential advantages of this construction are sensors reacting on careless behavior of the machine operator (e.g. holding the material in hand while it is being bent). Thanks to these protections the press does not move out the piston rods, which only takes place when the operator starts it with his/her both hands.

The main drawback of the press are their large dimensions, which justified taking into account the amount of cylinders and the generated load. Another disadvantage of the proposed appliance is a small table, which cannot be larger for the strength reasons.

Summarizing, the proposed appliance was designed to speed up the forming process - three cylinders working simultaneously. It requires further modernization, including changes in the electropneumatic and electric systems.

\section{References}

[1] Erbel, S., Kuczyński, K., Marciniak, Z., (1986). Techniki wytwarzania - obróbka plastyczna, PWN, Warszawa

[2] Górecki, A.r (2002). Technologia Maszyn. WSiP, Warszawa

[3] Marciniak, H.,(1983). Projektowanie procesów technologicznych, Wydawnictwo PWr, Wrocław

[4] Szenajch, W., (1997). Napęd i sterowanie pneumatyczne, WNT, Warszawa

[5] Świder, J., Baier, A., Kost, G., Zdanowicz, R., (2008). Sterowanie i automatyzacja procesów technologicznych i układów mechatronicznych - układy pneumatyczne i elektropneumatyczne ze sterowaniem logicznym (PLC), Wydawnictwo PŚl, Gliwice

[6] Węsierski, Ł. (1990), Podstawy pneumatyki, Wydawnictwo AGH, Kraków

[7] Węsierski, Ł., Łebkowski, P.,(1989), Zbiór zadań z projektowania układów pneumatycznych, OBREiUP, Kielce

[8] Kamo-Libio, M., (2015), Projekt konstrukcyjny i technologiczny pneumatycznej giętarki do plastycznego kształtowania blach, Uniwersytet Zielonogórski, Zielona Góra

[9] EMG pneumatic Press corporate - Catalogue, dane z 2015 roku

[10] Kraftpressar - Pneumatisska presar - Catalogue, dane z 2015 roku

[11] Tomczak, J., Bartnicki J., Maszyny i urządzenia do obróbki plastycznej, from: http://bc.pollub.pl/Content/1369/ maszyny.pdf 
[12] Bass Polska. Prasy hydrauliczne warsztatowe i hydrauliczno-pneumatyczne, from: http://www.basspolska.com

[13] Germantech. Giętarka do rur, from: http://germantech.pl/ product-pol-26962-02026962-Gietarka-do-rur-pneumatyczna-GermanTech-3-16-T.html

[14] Virgala, I., Frankovský, P., Kenderova, M. (2013). Friction Effect Analysis of a DC Motor. In: American Journal of Mechanical Engineering, 1(1), 1-5.

[15] Gmiterko, A., Virgala, I., Vacková, M.: Dynamic Analysis of the Two-Mass System to Imitate Rectilinear Motion of a Snake. In: Acta Mechanica Slovaca. Roč. 14, č. 4 (2010), s. 74-81.

\section{Biographical notes}

Joanna Cyganiuk, PhD, eng, was born in 1972. She is a scientific-didactic researcher working on Assistant Professor post in the Institute of Machine Building and Operation at the Mechanical Faculty at the University of Zielona Góra - Poland. She specializes in the analysis of the flow of bulk materials in pouring points of conveyor transport systems. She is also familiar with pneumatics and hydraulics as well as electrically controlled pneumatic and hydraulic systems. 